\title{
Influence of lactose on phosphate metabolism in rats
}

\author{
BY HANNA DEZBIEC AND ROMAN LORENC \\ Department of Biochemistry and Experimental Medicine, Hospital Monument Child's \\ Health Centre, 04-736 Warsaw, Al. Dzieci Polskich 20, Poland
}

(Received 24 March 1987 - Accepted I1 August 1987)

1. Lactose, sucrose or maltose were administered to rats by gavage together with ${ }^{32} \mathrm{PO}_{4}$, and blood ${ }^{32} \mathrm{P}$ was determined.

2. $\mathrm{PO}_{4}$ uptake into blood was increased only when lactose and $\mathrm{PO}_{4}$ were administered into the gut.

3. Weaned male rats were fed on a control diet or a diet containing 30,60 or $120 \mathrm{~g}$ lactose $/ \mathrm{kg}$. After a $5 \mathrm{~d}$ period of adaptation, a $6 \mathrm{~d} \mathbf{P}$ balance was carried out. After a further $24 \mathrm{~d}$ blood levels of $\mathrm{PO}_{4}$, and calcium and $\mathrm{PO}_{4}$ uptake by brush-border membrane vesicles prepared from the renal cortex, were determined.

4. The absorption and retention of $\mathbf{P}$ were higher in lactose-fed rats. Faecal $\mathbf{P}$ excretion decreased with increasing dietary lactose content. Urinary $\mathrm{P}$ excretion was lower in the rats fed on 30 and $60 \mathrm{~g}$ lactose $/ \mathrm{kg}$ whereas the $120 \mathrm{~g}$ lactose $/ \mathrm{kg}$ diet increased urinary $P$.

5. Membrane vesicles isolated from rats fed on the diets containing 30 and $60 \mathrm{~g}$ lactose $/ \mathrm{kg}$ showed a higher uptake of $\mathrm{PO}_{4}$, but with the $120 \mathrm{~g}$ lactose $/ \mathrm{kg}$ diet uptake was lower than with membrane vesicles isolated from rats fed on the control diet.

6. A statistically significant increase in the serum $\mathrm{PO}_{4}$ level was observed in the rats fed on the diet with $120 \mathrm{~g}$ lactose $/ \mathrm{kg}$.

7. The presence of lactose in the diet caused a stimulatory effect on $\mathrm{PO}_{4}$ absorption and retention.

Absorption of mineral components as well as mineral metabolism depends on the ingested diet. Dietary lactose has been shown to increase the retention of divalent cations, probably by facilitating their intestinal absorption (Lengeman, 1961; Amine \& Hegsted, 1971; Bushnell \& De Luca, 1981). In contrast, there is considerably less information available on the effect of lactose on phosphorus metabolism. In our earlier in vitro experiments using brush-border membrane vesicles (BBMV) prepared from intestinal mucosa and everted gut sacs, we found that lactose increased phosphate transport (Dębiec \& Lorenc, 1984, 1985). To our knowledge, however, the influence of lactose on the absorption of $\mathrm{PO}_{4}$ has not been investigated in vivo. The aim of the present study was to determine whether dietary lactose can enhance intestinal absorption of $\mathrm{PO}_{4}$ and increase its retention by the animal.

\section{MATERIALS AND METHODS}

\section{Expt 1}

Male Wistar outbred rats, fed on a commercial pelleted diet (Murigran; Central Laboratory of the Animal Food Industry, Lublin, Poland), were fasted overnight before treatment which consisted of a single intubation of the solution to be tested on day 28 after birth. The dosing solution $(1.0 \mathrm{ml})$, containing $40 \mu \mathrm{Ci}{ }^{32} \mathrm{PO}_{4}(0.1 \mathrm{ml} 0.01 \mathrm{M}$-potassium phosphate carrier) and 0 or $3 \mathrm{mg}$ lactose, maltose or sucrose $/ \mathrm{g}$ body-weight was administered by gavage. At 1.5,3,5 and $24 \mathrm{~h}$ after dosing, animals were killed by decapitation and blood collected. The blood samples were dissolved overnight in Nuclear Chicago Solubilizer (NCS) and placed in scintillation vials with scintillation solution. The amounts of ${ }^{32} \mathrm{P}$ in blood samples were determined by liquid-scintillation counting using a Beckman counter. 
Table 1. Composition of control diet $\ddagger(\mathrm{g} / \mathrm{kg})$

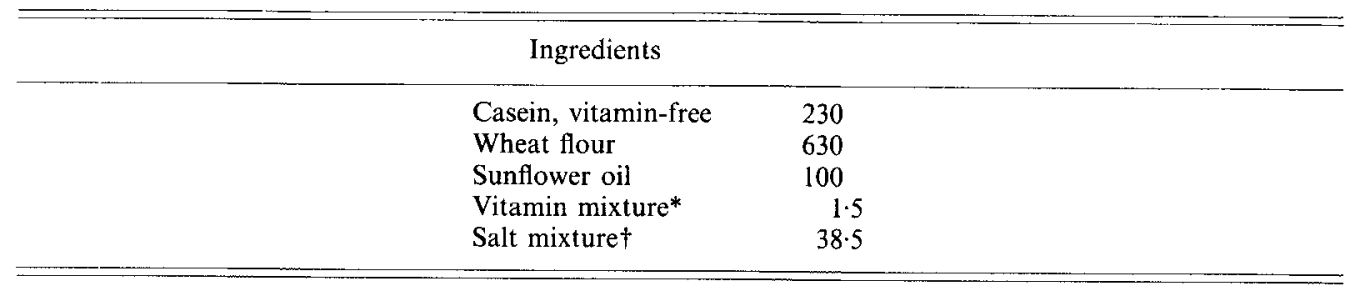

* Provided the following ( $\mathrm{mg} / \mathrm{kg}$ diet): choline chloride 1000 , myo-inositol 400 , nicotinic acid 20 , calcium pantothenate $20, p$-aminobenzoic acid 10 , folic acid $5 \cdot 6$, thiamin hydrochloride 5 , biotin $0 \cdot 3$, retinoic acid 1.76 , cholecalciferol 0.042

$\dagger$ Provided (mg/kg diet): $\mathrm{CuSO}_{4} .5 \mathrm{H}_{2} \mathrm{O} 15, \mathrm{MnSO}_{4} .5 \mathrm{H}_{2} \mathrm{O} 160, \mathrm{CoCl}_{2} 1, \mathrm{KI} 20, \mathrm{NaF} 50, \mathrm{ZnSO}_{4} .7 \mathrm{H}_{2} \mathrm{O} 1$, $\mathrm{NaBr} 20, \mathrm{Na}_{2} \mathrm{MnO}_{2} .2 \mathrm{H}_{2} \mathrm{O} 10, \mathrm{MgSO}_{4} .7 \mathrm{H}_{2} \mathrm{O} 4000, \mathrm{KCl} 3500, \mathrm{NaCl} 1500, \mathrm{KH}_{2} \mathrm{PO}_{4} 7600, \mathrm{NaH}_{2} \mathrm{PO}_{4} . \mathrm{H}_{2} \mathrm{O} 7700$, $\mathrm{CaCO}_{3} 14000$.

\$ Diet contained the following trace elements determined by analysis $(\mathrm{mg} / \mathrm{kg}$ diet): zinc 26 , iron 32 , selenium $0 \cdot 1$, chromium $0 \cdot 4$.

\section{Expt 2}

Wistar outbred male rats, weaned $18 \mathrm{~d}$ after birth, were fed on the following experimental diets: group 1, control diet; groups 2, 3 and 4, 30,60 or $120 \mathrm{~g}$ lactose $/ \mathrm{kg}$ respectively as a substitute for equivalent amounts of wheat flour. The composition of the control diet is presented in Table 1.

After $5 \mathrm{~d}$ of adaptation a $6 \mathrm{~d} \mathrm{P}$ balance was carried out. Metabolic-balance measurements were performed with each rat housed in an individual stainless-steel metabolism cage. The daily amount of ingested food was measured. Urine and faeces from each rat were pooled and analysed for $P$ content. Faecal samples were digested in acid before being analysed for $\mathrm{P}$ content. $\mathrm{P}$ retention was calculated as $\mathrm{P}$ intake minus $\mathrm{P}$ excretion in the urine and faeces, and $\mathrm{P}$ absorption as $\mathrm{P}$ ingested minus $\mathrm{P}$ excreted in the faeces; all these values were then expressed as a percentage of intake. After the balance studies the rats were removed from the metabolism cages and were offered the same diet for the following $24 \mathrm{~d}$. They were then killed. Blood was collected for calcium and $\mathrm{PO}_{4}$ analysis and the kidneys rapidly removed for inorganic $\mathrm{PO}_{4}$ transport studies.

\section{Brush-border membrane isolation and transport studies}

BBMV from the renal cortex were isolated by the Ca-precipitation method described by Evers et al. (1979). The final membrane buffer contained $100 \mathrm{~mm}-$ mannitol and $20 \mathrm{~mm}-$ Hepes-Tris, pH 7.4. Uptake of labelled substrates by the isolated membrane vesicles was measured by a Millipore filtration technique. $\mathrm{PO}_{4}$ uptake was studied in a medium

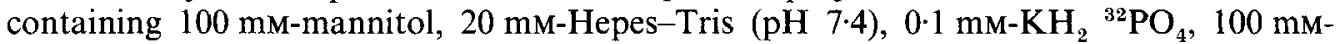
sodium chloride. The uptake experiments were initiated by the addition of approximately $50 \mu \mathrm{g}(20 \mu \mathrm{l})$ membrane protein to the incubation medium $(120 \mu \mathrm{l})$ and terminated by the removal of a $20 \mu \mathrm{l}$ portion which was subsequently filtered on Millipore $45 \mu \mathrm{m}$ filters. The filters were immediately washed with $10 \mathrm{ml}$ ice-cold stop solution containing $150 \mathrm{~mm}$ mannitol, $0.1 \mathrm{M}$-sodium chloride, $20 \mathrm{~mm}$-Hepes-Tris (pH 7.4), $10 \mathrm{~mm}$-sodium arsenate. The amount of ${ }^{32} \mathrm{P}$ retained on the filter was determined by liquid-scintillation counting.

Protein in the membrane preparation was determined after precipitation with trichloroacetic acid and solubilization with sodium hydroxide, by the method of Lowry et al. (1951). $\mathrm{PO}_{4}$ and $\mathrm{Ca}$ were determined colorimetrically (Zilversmit \& Davis, 1950; Grindler \& King, 1972). 


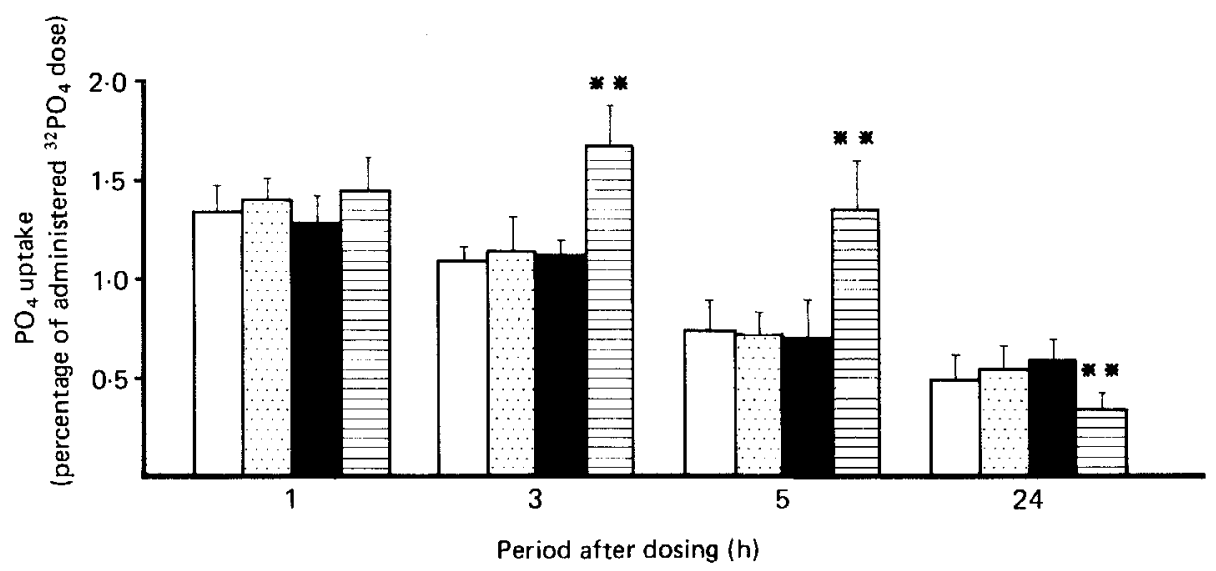

Fig. 1. Effects of maltose (图), sucrose ( $\square$ ), and lactose (圆), on phosphate uptake from the intestine into the blood of rats. ( $\square$ ), Control. Values are means, and standard deviations represented by vertical bars, expressed as a percentage of administered dose of ${ }^{32} \mathrm{PO}_{4} / \mathrm{ml}$ blood. Mean values were significantly different from those of the control group: ${ }^{* *} P<0.01$.

\section{Statistics}

The significance of differences between groups were evaluated using Student's $t$ test. All results are given as means and standard deviations.

\section{RESULTS}

The $\mathrm{PO}_{4}$ flux from the intestine into blood is shown in Fig. 1. Similar amounts of $\mathrm{PO}_{4}$ were absorbed by all groups given sugars, and by the control group during the first $1.5 \mathrm{~h}$ after dosing. Within 3-5 h after dosing, maltose and saccharose produced $\mathrm{PO}_{4}$ uptakes comparable to that of the control group, whereas lactose increased $\mathrm{PO}_{4}$ uptake. At $24 \mathrm{~h}$ after dosing the lactose-treated animals showed a different pattern. The blood level of inorganic ${ }^{32} \mathrm{PO}_{4}$ was, in this case, only half that of the other experimental groups.

\section{Metabolic-balance studies}

Table 2 shows values for the $6 \mathrm{~d} \mathrm{P}$ balance in rats fed on diets with different lactose contents. Daily intakes of $\mathbf{P}$ on all diets were similar. Urinary $\mathbf{P}$ excretion was lower with 30 and $60 \mathrm{~g}$ lactose $/ \mathrm{kg}$ diet whereas the $120 \mathrm{~g}$ lactose $/ \mathrm{kg}$ diet increased urinary $P$. Increasing the dietary lactose content from 30 to $120 \mathrm{~g} / \mathrm{kg}$ caused a decrease in faecal $\mathbf{P}$ excretion. Consequently the absorption and retention of $\mathrm{P}$ were higher in lactose-fed rats than in rats fed on the control diet.

\section{Body-weight and serum indices}

After 5 weeks on the experimental diets, rats had higher body-weights compared with the controls when the dietary levels of lactose were $30 \mathrm{~g} / \mathrm{kg}$ (nearly significant) and $60 \mathrm{~g} / \mathrm{kg}$ (significant, $P<0.05$ ). The diet containing $120 \mathrm{~g}$ lactose $/ \mathrm{kg}$ did not affect body-weight. In all rats on lactose-supplemented diets small, non-significant increases in the serum Ca level were observed. A significant $(P<0.05)$ increase in the serum inorganic $\mathrm{PO}_{4}$ level was observed only in the rats fed on the diet containing $120 \mathrm{~g}$ lactose $/ \mathrm{kg}$. The results are summarized in Table 3. 
Table 2. Expt 2. The effect of dietary lactose on phosphorus balance in rats

(Mean values and standard deviations for six rats/group)

\begin{tabular}{|c|c|c|c|c|}
\hline Dietary lactose $(\mathrm{g} / \mathrm{kg})$. & 0 & 30 & 60 & 120 \\
\hline \multicolumn{5}{|l|}{$P$ intake $(\mathrm{mg} / \mathrm{d})$} \\
\hline Mean & $25 \cdot 4$ & $22 \cdot 5$ & 23.9 & $23 \cdot 3$ \\
\hline $\mathrm{SD}$ & 3.7 & $3 \cdot 5$ & $4 \cdot 2$ & $3 \cdot 1$ \\
\hline \multicolumn{5}{|l|}{ Faecal P (mg/d) } \\
\hline Mean & $8 \cdot 9$ & $4 \cdot 3^{*}$ & $4 \cdot 4^{*}$ & $2 \cdot 5^{*}$ \\
\hline SD & $1 \cdot 6$ & 0.9 & $0 \cdot 5$ & $0 \cdot 3$ \\
\hline \multicolumn{5}{|l|}{ Urinary $P(m g / d)$} \\
\hline Mean & $4 \cdot 4$ & $2 \cdot 5^{*}$ & $2 \cdot 8^{*}$ & $5 \cdot 1^{*}$ \\
\hline SD & $0 \cdot 3$ & $0 \cdot 4$ & $0 \cdot 7$ & $0 \cdot 3$ \\
\hline \multicolumn{5}{|l|}{ P absorption ( $\%)$} \\
\hline Mean & $65 \cdot 3$ & $85 \cdot 5^{*}$ & $81 \cdot 7^{*}$ & $88 \cdot 5^{*}$ \\
\hline SD & $2 \cdot 5$ & $5 \cdot 8$ & $6 \cdot 1$ & $5 \cdot 1$ \\
\hline \multicolumn{5}{|l|}{$\mathrm{P}$ retention $(\%)$} \\
\hline Mean & $47 \cdot 9$ & $69 \cdot 2^{*}$ & $69 \cdot 8^{*}$ & $66 \cdot 0^{*}$ \\
\hline $\mathrm{SD}$ & $2 \cdot 1$ & $4 \cdot 9$ & $5 \cdot 6$ & $4 \cdot 2$ \\
\hline
\end{tabular}

Mean values were significantly different from those of the control group: ${ }^{*} P<0 \cdot 05$.

Table 3. Body-weights and serum calcium and phosphate concentrations of rats fed on diets of differing lactose contents $\dagger$

(Mean values and standard deviations for six rats/group)

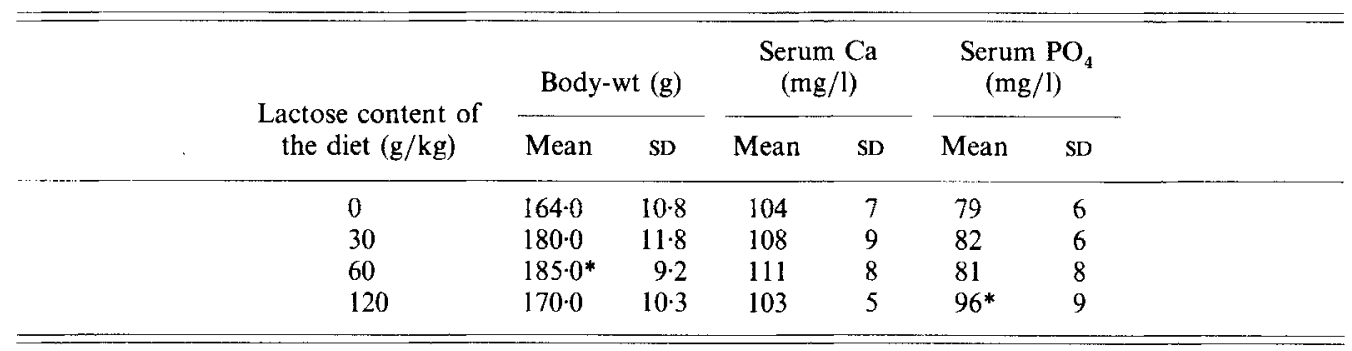

Mean values were significantly different from those of the control group: ${ }^{*} P<0.05$.

$\dagger$ Weaning rats were maintained on a semi-synthetic diet for 5 weeks. Experimental groups received 30,60 or $120 \mathrm{~g}$ lactose $/ \mathrm{kg}$, substituted for an equivalent amount of wheat flour in the diet.

\section{Transport properties of $B B M V$}

Dietary lactose influenced inorganic $\mathrm{PO}_{4}$ uptake into $\mathrm{BBMV}$ isolated from the renal cortex (Fig. 2). BBMV isolated from rats fed for 5 weeks on the diet with 30 and $60 \mathrm{~g}$ lactose $/ \mathrm{kg}$ showed a higher uptake of inorganic $\mathrm{PO}_{4}$ whereas with $120 \mathrm{~g}$ lactose $/ \mathrm{kg}$ uptake of inorganic $\mathrm{PO}_{4}$ was lower than with BBMV isolated from rats fed on the control diet.

\section{DISCUSSION}

The present results demonstrate that lactose enhances the efficiency of $\mathrm{PO}_{4}$ absorption and retention in the rat. $\mathrm{PO}_{4}$ uptake into blood was increased when lactose and $\mathrm{PO}_{4}$ were administered simultaneously into the gut. This suggests an immediate influence of lactose 


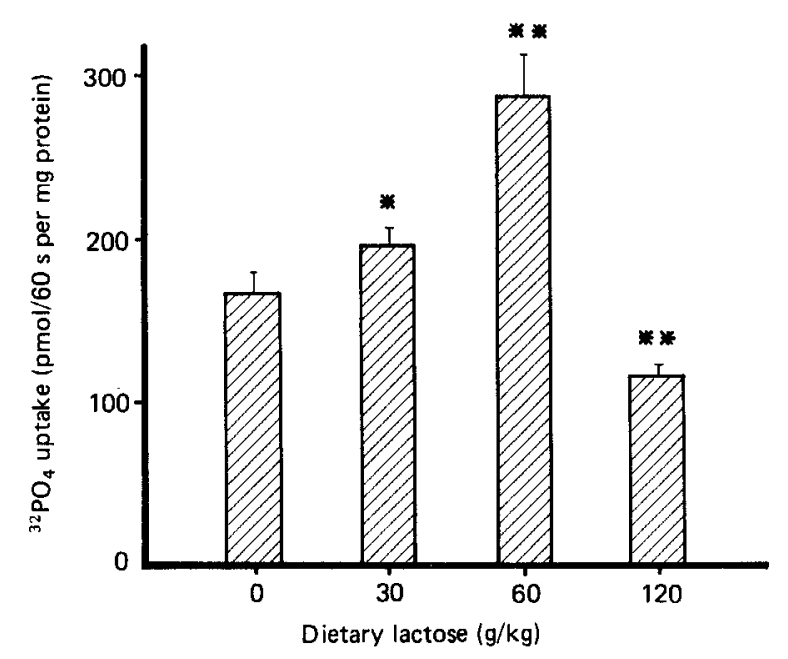

Fig. 2. The effect of dietary lactose on the sodium-dependent phosphate uptake by renal brush-border membrane vesicles of rats. Values are means, and standard deviations represented by vertical bars. Mean values were significantly different from those of the control group: ${ }^{*} P<0.05,{ }^{* *} P<0.005$.

on intestinal transport processes. Other sugars tested, namely sucrose and maltose, were without effect. The observed differences can be connected with the activity of intestinal disaccharidases. In weaned rats lactase (EC 3.2.1.108) activity in the intestine is very low, thus lactose is hydrolyzed and absorbed very slowly (Goldstein et al. 1971). Several hours after administration, large amounts of lactose are present in the intestine where it can influence the absorption of minerals (Dahlquist \& Thomson, 1964). In contrast, maltose and sucrose are quickly hydrolyzed and monosaccharides are absorbed in the upper part of the intestine. Therefore rapid removal of these disaccharides from the intestine can account for their ineffectiveness. Increased intestinal absorption of $\mathrm{PO}_{4}$ in the presence of lactose was confirmed by metabolic-balance studies. Animals consuming lactose have a lower faecal P loss and consequently higher absorption of this mineral. Increasing the lactose level in the diet from 30 to $120 \mathrm{~g} / \mathrm{kg}$ caused a progressive increase in absorption of $\mathrm{P}$. A similar relation between the effect of lactose on Ca absorption and the amount of this carbohydrate in the diet has been noted (Fournier \& Dupuis, 1962).

Additionally, our results show that lactose feeding changed the urinary excretion of $P$. The direction of the changes depended on the lactose content of the diet. A decrease in urinary $P$ excretion was observed in rats fed on diets with 30 and $60 \mathrm{~g}$ lactose $/ \mathrm{kg}$ while the urinary loss of $\mathrm{P}$ was higher in the case of rats fed on $120 \mathrm{~g}$ lactose $/ \mathrm{kg}$ diet. However, in all cases the overall retention of $P$ in rats fed on the lactose diet was higher in comparison with the control group. The changes in urinary excretion of $\mathrm{P}$ with the lactose diet did not appear to be correlated directly with the effect of lactose on the reabsorption of $P$ in the kidney. The observed reduction in urinary $P$ excretion may be dependent on the parathyroid hormone (PTH) status of the animal. Although we cannot directly measure PTH levels this hypothesis is supported by the following observations. The slightly increased serum level of $\mathrm{Ca}$ in lactose-fed rats could increase the level of ionized serum $\mathrm{Ca}$. This in turn would inhibit the secretion of PTH and could lead to a decrease in urinary P. The changes in renal reabsorption of $\mathrm{PO}_{4}$ are expressed at the level of the brush-border membrane by a change in the sodium-dependent transport of inorganic $\mathrm{PO}_{4}$. Thyroparathyroidectomy and reduction of serum PTH level have been shown to increase the 
rate of the $\mathrm{Na}^{+}$-dependent $\mathrm{PO}_{4}$ uptake by $\mathrm{BBMV}$ as well as renal reabsorption of $\mathrm{PO}_{4}$ (Hammerman et al. 1983; Ullrich et al. 1977). Therefore the present results suggest that the observed increase in $\mathrm{PO}_{4}$ uptake by BBMV isolated from rats fed on diets containing 30 and $60 \mathrm{~g}$ lactose $/ \mathrm{kg}$ may be associated with decreased PTH levels.

Different results were observed in rats fed on the $120 \mathrm{~g}$ lactose $/ \mathrm{kg}$ diet. In this case urinary excretion of $P$ increased and this was correlated with decreased capacity of BBMV to take up inorganic $\mathrm{PO}_{4}$. Moreover, in this group, absorption of $\mathrm{P}$ was the highest and the serum $\mathrm{PO}_{4}$ level was raised. Thus, the present findings could be explained by an adaptation to dietary $\mathrm{P}$ absorption. The capacity of the kidney to reabsorb $\mathrm{PO}_{4}$ decreases in response to a high-P diet (Stoll et al. 1979a). These dietary-induced adjustments are independent of PTH, vitamin D and serum Ca level (Stoll et al. 1979 b).

Finally, the lack of an effect on body-weight of the diet supplemented with $120 \mathrm{~g}$ lactose $/ \mathrm{kg}$ can be related to increased losses of protein and fat in rats fed on diets containing higher amounts of lactose (Leichter \& Tolensky, 1975).

In conclusion our findings indicate that the presence of lactose in the diet stimulated $P$ absorption and retention. The mechanism of the lactose effect on $\mathrm{Ca}$ and $\mathrm{PO}_{4}$ metabolism is complex and involves a direct effect of lactose on the intestine as well as stimulation of several adaptative and hormonal mechanisms.

The present work was supported by Grant no. JMOA-USDA-4. The authors thank $\mathrm{Mr}$ Krzysztof Lancman for capable technical assistance.

\section{REFERENCES}

Amine, E. K. \& Hegsted, E. (1971). Journal of Nutrition 101, 927-934.

Bushnell, P. J. \& De Luca, H. F. (1981). Science 211, $61-63$.

Dahlquist, A. \& Thomson, D. L. (1964). Acta Physiologica Scandinavica 61, 20-23.

Dębiec, H. \& Lorenc, R. S. (1984). In Epithelial Calcium and Phosphate Transport: Molecular and Cellular Aspects, pp. 241-245 [F. Bronner and H. Peterlik, editors]. New York: Alan R. Liss.

Dębiec, H. \& Lorenc, R. S. (1985). Journal of Nutrition 115, 1168-1172.

Evers, C., Haase, W., Murer, H. \& Kinne, R. (1979). Journal of Membrane Biochemistry 1, 203-219.

Fournier, P. L. \& Dupuis, Y. (1962). Compte rendu de l'Académie des Sciences 255, 1649-1656.

Goldstein, R., Klein, T., Freirer, S. \& Menczel, J. (1971). American Journal of Clinical Nutrition 24, 1224-1231.

Grindler, E. M. \& King, J. D. (1972). American Journal of Clinical Pathology 58, 376-382.

Hammerman, M. R., Cohn, D. E., Tamayo, J. \& Martin, K. J. (1983), Archives of Biochemistry and Biophysics 227, 91-97.

Leichter, J. \& Tolensky, A. F. (1975). American Journal of Clinical Nutrition 28, 238-24l.

Lengman, F. W. (1961). American Journal of Physiology 200, 1051-1054.

Lowry, O. H., Rosebrough, N. J., Farr, A. L. \& Randall, R. J. (1951). Journal of Biological Chemistry 193, 265-275.

Stoll, R., Kinne, R. \& Murer, H. H. (1979a). Biochemical Journal 180, 465-479.

Stoll, R., Kinne, R., Murer, H. H., Fleisch, H. \& Bonjur, J. P. (1979b). Pfügers Archiv 380, 47-52.

Ullrich, K. J., Rumrich, G. \& Kloss, S. (1977). Pfiügers Archiv 372, 269-274.

Zilversmit, D. B. \& Davis, K. (1950). Journal of Laboratory and Clinical Medicine 35, 155-166. 